\title{
GRAMMATICAL CHANGES CAUSED BY CONTACT BETWEEN LIVONIAN AND LATVIAN ${ }^{1}$
}

\author{
Valts Ernštreits \\ University of Tartu
}

\section{Gunta Kliava}

University of Latvia, Rīga, and Latvian Language Agency

\begin{abstract}
The article provides insight into the process of various grammatical changes in Livonian and Latvian that have taken place as a result of prolonged contact between the languages. Livonian is strongly influenced by Latvian at different levels due to the close contact between the speakers of two languages; it is necessary to note that speakers of Livonian were bilinguals for a long time. It is clear that Livonian has affected Latvian in a similar way. The process of mutual borrowings can be observed most clearly in the vocabulary, especially in dialects; however, there are changes that have occurred in the phonetics and grammar as well. Different changes can be found as a result of mutual influence. The paper presents case studies illustrating the changes of the case system in Livonian - the disappearance of exterior locative cases and the formation of dative, the merging of the translative and the comitative and the formation of the instrumental, the development of prefixes from inherited words, composition of negation, as well as semantic changes in the Latvian locative, formation of Latvian compounds using the Livonian pattern, formation of perfective verb forms using the construction 'motion verb + adverb' instead of Latvian prefix verbs. Although the grammatical structure of a language is considered to be relatively resistant to change, grammatical changes may occur in languages that are not related but are located in close proximity to one another for a long time. The results of Livonian and Latvian contact demonstrate that clearly.
\end{abstract}

Keywords: Livonian language, Latvian language, language contacts, grammatical changes

DOI: http://dx.doi.org/10.12697/jeful.2014.5.1.05

1 The study was partly supported by the Estonian Research Council project IUT2-37. 


\section{Introduction}

Socio-linguistic context plays an important role in changes caused by language contacts. In order for grammatical changes to occur because of a contact language, firstly, these contacts need to be expressed as direct and active communication between the language speakers, and secondly, these contacts have to be intensive and permanent or continuous and with involvement of the maximum possible number of speakers in these contacts. Also, it must be taken into account that the changes which have occurred in the spoken language of bilinguals will be different from the changes caused by internal language factors of monolingual speakers, as languages spoken by bilinguals affect each other in different ways (Sankoff 2001: 638). Therefore, changes can occur because of language contacts, if there are regular and intensive contacts (individual and in the society), an appropriate linguistic situation (especially as regards language prestige, economic value and linguistic attitude), as well as already existing structural similarities between the languages.

Latvian and Livonian are not genetically related, but they do share a similar geographical location over a prolonged period of time, as a result of which they both contain traces of contact. Latvian and Livonian language speakers have been in contact for centuries, and inevitably this has caused various degrees of changes in both languages. Furthermore, both languages have been givers and receivers (Rudzite 1996: 3). Livonian has taken from Latvian many older and newer words, pronunciation characteristics, and grammatical forms, and in turn Livonian has enriched Latvian in the same way (Ernštreits 2011: 13). As a result of drawing conclusions and analyzing materials, it must be taken into account that there is still insufficient linguistically correct knowledge about the earlier history of Livonian (Bušs 2008: 200). There is also still an insufficient amount of information about mutual contacts between Livonian and Latvian and their influence on the development of both languages.

During the close and continuous contact with Latvians, bilingualism was widespread among Livonians for many centuries. When looking back at more recent history, it can be seen that after the First World War the Courland Livonian community was completely bilingual (Ernštreits 2011: 14; see also Rudzīte 1994: 288), especially when taking into account the higher status, prestige and economic value of the Latvian language. The reason for the influence of Livonian on Latvian is the vast expansion of the Latvian language area, starting from Livonian-inhabited territories around Lower Daugava and on both sides of the Gulf of Riga (today this is the area of Livo- 
nian dialects of Latvian). Furthermore, the basis of the Latvian literary language is formed by the Central Latvian dialect vernaculars, which have developed in the Livonian and Latvian territories populated by Baltic tribes in their contact zones in Vidzeme and Courland.

Changes caused by language contacts occur because speakers translate and search for equivalents in their language for the materials and categories to be translated; this process is related also to human thinking and its expression in language, changing and adjusting new material. In contact situations linguistic communities adopt speech genres, ways of forming narratives, and other elements of language (Aikhenvald, Dixon 2007: 17), adapting or borrowing entire grammatical concepts or structures. However, it must be added that this is possible only if the internal structure of the language allows it. It is essential that even the process of grammatical changes caused by language contacts occurs continuously and over a long period of time. This article tries to sketch the grammatical changes caused in Latvian and Livonian by mutual contacts, the analysis of which needs to be continued in further studies. When researching the linguistic expressions of Latvian-Livonian conflict, it must be taken into account that mutual influence has occurred over different time periods - even before and after the separate Baltic tribes assimilated with Latvians, as well as before and after Finnic languages had separated (Zinkevičius 1984: 181).

\section{Changes in the case system}

The most obvious Latvian influence on Livonian grammar is found in the Livonian case system, which has undergone extensive changes. It has lost exterior locative cases, the adessive and allative have almost entirely converged, the translative and comitative cases have merged, and a new case (the dative) has developed.

Changes in the Latvian case system caused by Livonian can be seen in the wider use of locative case in a directional case function, in accordance with the Finnic case system.

In Finnic languages, the expression of a location uses three exterior locative (to (direction), to (place), from outside) and three interior locative (in (direction), in (place), from inside) cases, which indicate the direction and localization. In Livonian language speakers' conscience, this old system has lost clarity as a result of the influence of Latvian, as exterior locative cases have almost completely disappeared from the spoken language and remain intact only in adverbs related to time and place, for example kõrval 'next to', as well as separate 
toponym groups, for example, Irēel 'in Mazirbe $\sim$ to Mazirbe'. Since 1930 s, there has been an effort to restore these cases in Livonian; therefore, exterior locative case can be seen in Livonian language (especially written) examples. However, they have not regained full paradigmatic use. At the same time, wherever exterior locative cases rudimentarily remain, for example, in adverbs and toponyms, the adessive and allative have mostly fully converged and there is no longer any distinction between them, for example, almõ-l 'downwards $\sim$ down', Est. allapoole (ALL) allpool (ADE); Sīkrõgõ-l 'in Sīkrags to Sīkrags'; lekštā Irēel 'went to Mazirbe', Est. läksid Irē-le (ALL) (LEL); ta jelāb Irēel 'he lives in Mazirbe', Est. ta elab Irēl (ADE).

In Latvian, such exterior locative meanings are mostly expressed with the help of prepositions (e.g., uz tirgus, uz lauka) and similar constructions replacing exterior locative cases can also be seen in Livonian (tõrg pä́l, nurm pä̈l 'on the market, on the field'; Est. turu-l, nurme-l (ADE) 'on the market in the market, on the field'; tõrg päld, nurm päld 'from the market, from the field'; Est. turu-lt (ABL), nurme-lt 'from the market, from the field'). Constructions replacing or working in parallel with exterior locative cases are possible in other Finnic languages with the use of auxiliary verbs; however, in Livonian these constructions have completely replaced exterior locative cases.

\begin{tabular}{|c|c|c|}
\hline $\begin{array}{l}\text { aimrovzt } \\
\text { homestead people }\end{array}$ & $\begin{array}{l}\text { lekšs-tõ } \\
\text { go.PST-3PL }\end{array}$ & $\begin{array}{l}\boldsymbol{t} \tilde{\boldsymbol{o r g}} \\
\text { market.GEN }\end{array}$ \\
\hline ple & to market' & \\
\hline
\end{tabular}

Latvian contains different uses of locative than those found in related languages (Lithuanian, Russian, etc.). Combined with guidance verbs, in addition to the location meaning, the locative also possesses a directional meaning, i.e., locative is used not only to indicate the location, but also motion to something, which in related languages is expressed using prepositional constructions, e.g., Latv. es braucu Rig $\bar{a}$ 'I am driving to Riga' (LOC), Lith. aš važiuoju i Ryga (i + ACC), Rus. я едy в Puzy, however, Liv. ma broutšõ $b$ Rīgõ (ILL), Est. ma sõidan Riiga (ILL); Latv. krist zemē 'to fall on the ground' (LOC; also $\sim$ krist uz zemes), Lith. kristi ant žemés (ant + GEN), Rus. падать на землю, but Liv. mōzõ saddõ (ILL), Est. maha kukkuma (ILL).

The formation of the oldest Baltic locative cases (inessive, illative, adessive, allative) can be explained by the Finnic influence, where the Latvian illative (with directional meaning) can be found only in the oldest texts and elsewhere in dialects remains the Lithuanian language illative with $-n$, which is used in a directional meaning, because the 
Lithuanian locative only has a locative meaning (Endzelīns 1951: 589; Seržants 2012: 61; Zinkevičius 1984: 180). However, the directional illative has combined with the location-indicatingcase (inessive), and the locative in Latvian also has a directional meaning (dzīvot Rigg $\bar{a}$ (INE) 'to live in Riga' and braukt Rìg $\bar{a}$ (ILL) 'to travel to Riga'), which often uses prepositional constructions as in other related languages to differentiate both meanings (braukt uz Rigu 'to travel into Riga'). The semantically broad and varied locative case system is also characteristic of other Finno-Ugric languages, but the semantic changes of the locative in Latvian are most likely related to the close contacts between the two languages. Furthermore, the changes in the case system and semantics in both languages show mutual influences and the search for common linguistic approaches essential to the language contact process (Seržants 2012: 66).

Finnic exterior locative cases (ADE and ALL) are also used to express dative meanings (e.g., Est. minu-le, Fin. minu-lle (ALL) 'to me (direction)'; Est. minu-l, Fin. minu-lla (ADE) 'to me'); however, Livonian uses a new case with full paradigm due to the influence of

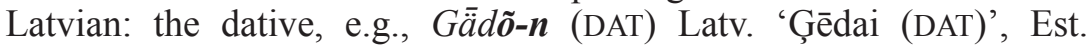
Gäda-le (ALL).

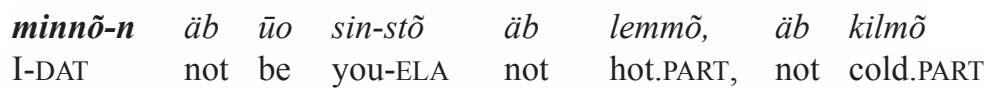

'I am not hot, not cold for you I do not care about you'

Est. minul (ADE) pole sinust ei sooja ega külma (LEL)

It is significant that exterior locative case in dative meaning remains in Salaca Livonian (most likely thanks to contacts with Esto-

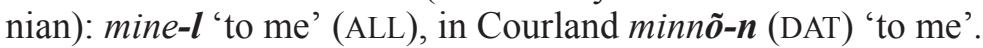

It must be added that the origin of the dative ending -( $\tilde{o}) n$ in Livonian is most likely related to the extinct essive case in Livonian *-nA (see also ě̌žõm pǟva-n 'on Monday', Est. esimese-na 'as first, in first position', Fin. päivä-n̈̈ 'during day'); a certain part could be attributed to the old genitive ending $*_{-} n$, which remains completely intact in Finnish (päivä-n (GEN) 'days') and in separate compounds in Livonian and Estonian languages (jōra-n|aiga 'on the lakeside', Est. maa-n|tee 'road, highway'). The creation or preservation of the Livonian dative ending, influenced by the earlier Latvian illative ending, also has to be acknowledged.

Similarities and differences in the use of dative and exterior locative cases can be clearly seen in the following examples: $a^{\prime} b$ kuo'igmieztõ-n (DAT.PL) 'assistance to sailors (DAT.PL)', Est. abi

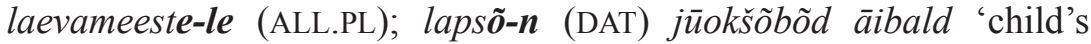


(DAT) saliva trickles', Est. lapsel (ADE) jookseb ila; agāņi jelājidõn (DAT.PL) iz siet 'chaff wasn't fed to animals (DAT.PL)', Est. aganaid loomadele (ALL.PL) ei söödetud (LEL).

As a result of Latvian influence, the Livonian translative and comitative cases have merged (Ernštreits 2011: 30), forming another case, which, following the Latvian language example, is called the instrumental (earlier, this case was also called the translativecomitative).

As a result of active contacts, the reanalysis of the Livonian language translative case suffix is encouraged (the Livonian instrumental marker is $-k s$ for multi-syllabic roots and $-k \tilde{o} k s$ for mono-syllabic roots); one morpheme expresses two different functions (Grünthal 2003: 177, 182), for example, aršstõks '[together] with a doctor $\sim$ [become] a doctor'. This grammatical change could be caused by internal factors, but could also have happened as a result of language contacts. In this case, the change is not simply a mechanical adoption of a construction, but an expansion by analogy. However, it must be noted that the expansion process has been more complex in words with monosyllabic roots, because the initial translative ending * $*_{k}$ seems to be combined with the initial comitative ending $*_{-} k a$, i.e., $*_{-k a}+*_{-k s}>*_{-k a k s}>-k \tilde{k} k s$. Such words in separate cases have also retained different forms for translative and comitative reproduction, e.g., piņ'kõks (COM) 'with dog', pi'ņñôks (TRA) '[grow up] to be a dog'.

Since in Latvian these two different relations are expressed with a single morphological category, Livonian language speakers have adopted it as well. The morphosyntactic characteristics of the Latvian instrumental case, presumably, have been the impetus for the development of the Livonian instrumental case (Grünthal 2003: 205). This is also shown by the frequent preposition $\mathrm{pa}$ 'about, for', borrowed from Latvian, for example, pa sürõks '[become] large', which was used to emphasize the difference between translative and comitative (Ernštreits 2011: 30). The construction with the preposition usually expresses only the translative meaning, but not the comitative meaning (Grünthal 2003: 182).

The attribution of the translative marker to the instrument is illustrated by the following examples:

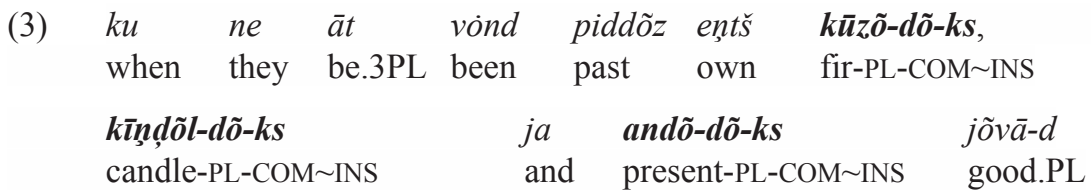




$\begin{array}{lllll}\text { lapst } & \text { pierāst, } & \text { siz } & \bar{\imath} r g o ̃ b & \text { tōla } \\ \text { child.PL } & \text { later, } & \text { then } & \text { begin.3SG } & \text { winter }\end{array}$

'when they have passed with fir-trees, candles and presents for good children, winter began'(JS 2011: 14)

(4)

$\begin{array}{llll}\text { aimõ }-\boldsymbol{k s} & \text { kītizt } & \text { perīmīe } & \text { aim } \\ \text { household-INS } & \text { say.3PL } & \text { houseowner } & \text { family }\end{array}$

'the houseowner's family was called the household'

Est. pereks (TRA) kutsuti peremehe perekonda (LEL)

(5)

\begin{tabular}{|c|c|c|c|}
\hline $\begin{array}{l}m \bar{e} g \\
\text { we }\end{array}$ & $\begin{array}{l}\text { sōmõ } \\
\text { get_along.1PL }\end{array}$ & $\begin{array}{l}\overline{\boldsymbol{i}} \boldsymbol{d t u o i z - k \tilde { o } \boldsymbol { k s }} \\
\text { each_other-INS }\end{array}$ & $\begin{array}{l}l e ' b b \tilde{o} \\
\text { at_the_end }\end{array}$ \\
\hline & me üksteisega & M) läbi (LEL) & \\
\hline
\end{tabular}

\section{Changes in the use of prefix verbs and prefixes}

Alongside changes in the case system, language contacts have also caused grammatical changes regarding the appearance of prefixes in Livonian and the widespread use of adverbial constructions alongside or in combination with prefix verbs in Latvian.

Finnic languages do not have their own inherited prefixes; their functions are typically performed by affixal adverbs, as is the case in Livonian (Ernštreits 2011: 30; Vääri 1994: 281). However, in many places, Livonian speakers in the more recent times have used Latvian prefixes; furthermore, the full spectrum of prefixes has been borrowed. Using the adopted prefixes, words of different parts of speech are created. It must be emphasized that the semantic concordance with Latvian of combinations of inherited words with adopted prefixes is significant (Rudzīte 1996: 4), for example, samūoštab, Latv. saprot 'understands'; iegrumānikād, Latv. ienaidnieki 'enemies', piepōlab, Latv. pielūdz 'worships' and others.

It must be said that the use of Latvian language prefixes is a relatively new phenomenon and is not fully comprehensive, because, for example, in Vaide and Sìkrags the use of borrowed prefixes is much rarer or in some cases totally absent. Also, the borrowed prefixes were completely eradicated from the written Livonian language during the 1930s.

Separate inherited morphemes have also turned into prefixes during the continuation of the process of borrowing prefixes (Laakso 2010: 604). The prepositions or postpositions can become prefixes, 
even going through the socalled middle state and becoming prefixoids, i.e., an intermediate stage during the development of a language element which is neither a root nor a prefix (van Goethem 2008). In Livonian, this process can be found in the following cases, for example, ilzo (adverb) 'upwards' (intermediate stage - prefixoid:

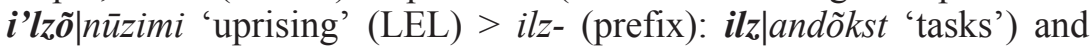

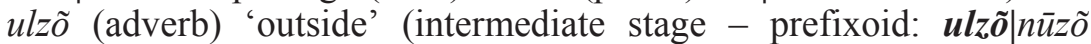
'arise' (LEL) > ulz- (prefix): ulz|ändaji 'publisher'). The morphological or semantic structure of these words often conforms to an example in another language. Additionally, similar prefixoids can be also found in the Estonian language (üles|tõusmine 'resurrection', välja|anne 'edition').

Following the example of Latvian, where the derivation of words with prefixes is productive, Livonian has not only borrowed prefixes, but also native Livonian words which have become prefixes, most likely to avoid analytical forms and following the principle of language economy. Furthermore, the relatively frequent use of the derivatives $i l z(\tilde{o})$ - and $u l z(\tilde{o})$ - points to a reasonable productivity which also has a significant role in the development and use of another phenomenon. For example, ilzandõks 'task' (JS 2011); ilznūzõ 'get up' (LEL); ilzpūgõ 'hang (a person)' (LEL); ulzandõnd 'issued' (JS 2011); ulzāndamt 'editions' (LEL); ulzrabbõm 'rashes' (LEL); ulzsōtõ 'exile, banish' (LEL); ulztūlda 'come out' (LEL), ulzvóstõ 'redeem' (LEL).

However, as a result of the influence of Livonian on Latvian, motion verb prefixes for expressing a completed action are sometimes replaced by constructions with adverbs characteristic of Finnic languages, for example, vērt valı ā atvērt 'to open', skriet prom aizskriet 'to run away', iet iekša $\bar{a} \sim$ ieiet 'to go in'; iet àra $\bar{a} \sim$ iziet 'to go out'. Completed form (perfective) verbs in Latvian are formed from imperfective verbs by adding prefixes to them, but there is widespread use of imperfective verb constructions with adverbs (kapt zeme 'to step down', slēgt val̄a 'to unlock', likt klāt 'to add' and others) (Endzelīns 1951: 961) instead of a Latvian prefix verb. J. Endzelīns points out that "the widespread use of replacement forms in Latvian can partially be attributed to Livonian Latvianizations". In modern Latvian, imperfect verb constructions with adverbs also express incomplete or ongoing actions.

Furthermore, newer constructions, which presumably have formed as a result of this process, are the constructions containing prefix verbs and adverbs. Prefixes have often lost their lexical meaning, and the adverb used in the construction specifies the meaning of the prefix (LVG 2013: 537). In actual use there are doubling prefix verb and 
adverb constructions, for example, uzlikt virsū 'to put on', iznemt ārā 'to take out', uzkāpt augšā 'to step up', ienākt iekšā 'to come in', pielikt klāt 'to add', aiziet projām 'to leave', atverrt val̦ā 'to open', aizbultèt ciet 'to close a lock'.

\section{Negative affixes in Livonian}

In Latvian, negation is formed with the prefix ne- or negative particle; however, in Finno-Ugric languages, negation is done by means of a negative auxiliary verb. In Livonian, the negative auxiliary $\ddot{a} b$ 'not' in certain contexts (when forming antonyms, and in rarer cases, individual verb forms), due to influences from Latvian, has lost the characteristics of an independent word and has gained affix characteristics (function word $>$ clitic $>$ affix). It should be noted that in the first publications in Livonian $\ddot{a} b$ is considered a clitic, because it is written separately, for example, äb jõvd,i (PART) 'not good' (Mt 1863), perceiving it as a negative particle (Ernštreits 2011: 42).

However, as a result of Latvian influence, this negative particle has also gained prefix characteristics and is mostly considered a prefix, especially taking into account the influence of Latvian on the development and use of prefixes in Livonian. It must be noted that unlike in Estonian and Finnish, where similar prefixes (Est. eba-, Fin. epä-) are unproductive and can mostly be observed in neologisms, in Livonian, just like in Latvian, the prefix $\ddot{a} b$ - is explicitly productive: $\ddot{a} \boldsymbol{b} k \bar{a}$ ndatiji 'impatient'; äbu'ndõb 'unforgettable'; äbeldi rištīng 'immoral person'; äbjõ'vvõ tī'edõ 'do evil'; äbloppõm 'infinity' (LEL); äbvantlõs 'despite' (pro vantlõmõt); äbmaksamõz 'not paying' (Statūti 1923); (..) ku äbjelzizt ažãd äb tūoḑõt kūožõst jarā likkõ (..) 'nonliving things cannot move from their place' (JS 2011); kēnig tidār ei äbknaššõks 'the princess became lunbeautiful' (LEL); tikkiž se aža vól $i k s ̌ s u ̈ r$ äbsieldit 'all of this was just a large uncertainty' (LEL)

\section{Changes in forming Livonian impersonals}

In Finnic languages, the passive is expressed by means of a separate verb category - the impersonal, which is formed by the use of morphological elements, e.g., Est. teha: tehakse, Fin. tehdä: tehdään 'do: one does'. These forms do not include any person or number marking. In Latvian, to express an action without mentioning the agent, it is possible to use the 3rd person form of the verb, which is common both for singular and plural. However, due to the influence of 
Latvian, Livonian has lost the impersonal verb form, and the indicative singular or plural third person form is used to express passive (the fluctuation between singular and plural is related to the absence of morphological differences between them in Latvian).

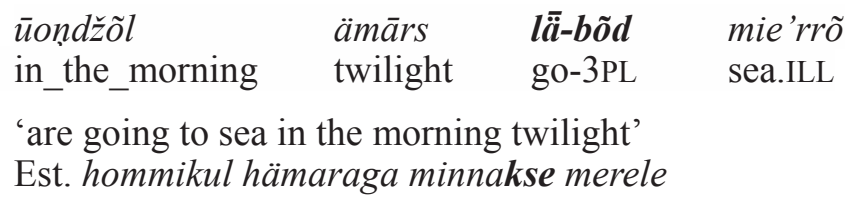

$\begin{array}{lll}\text { armijõ } & \boldsymbol{l} \overline{\boldsymbol{a}}-\boldsymbol{b} & \text { dīenõ-m } \\ \text { army } & \text { go-3SG } & \text { serve-SUP }\end{array}$

'goes to serve in the army'

Est. sõjaväkke minnakse teenima

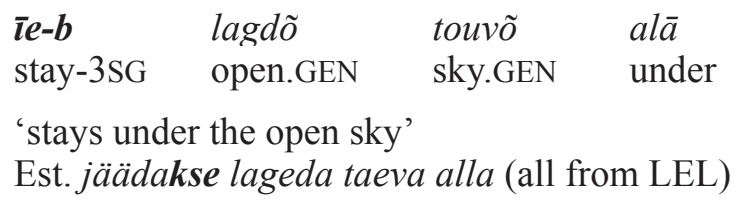

Furthermore, the impersonal with third person singular and plural endings is formed in both the present and past tense.
bilt-iz
biltõ
mill-PST.3SG
mill_flour.PART
'mill flour was milled'
Est. püüliti püüli
$\boldsymbol{s} \overline{\boldsymbol{t}} \boldsymbol{t}-\boldsymbol{i z} \boldsymbol{t}$
send-PST.3PL
$a m z ̌ i$
everywhere
'he was sent everywhere'
Est. teda saadeti kõikjale (all from LEL)

(10) tända
he. PART

\section{Formation of compounds}

In Latvian, compounding is a productive method of creating new words. Usually in Latvian, to identify an object or a place, which is under something, which is usually a primary word, a prefixal noun with prefix $p a$ - is formed; however, to identify a place, which is behind an object, the prefix aiz- is used, for example, pagalde 'under the 
table', paklète 'under the granary', pagulte 'under the bed', aizdurve 'behind the door'. However, most likely, following the example of Livonian, such location names are also formed as compounds, where the second component is apakša and pakaļa, for example, kütspakala 'behind the barn', galdapakša 'under the table', klètsapakša 'under the granary', gultapakša 'under the bed'. It must be noted that the use of compounds based on postpositional phrases is found in specifically Livonian dialects of Latvian, which are spoken in territories formerly populated by Livonians. In Livonian, the formation of these compounds is common and productive, for example, aitanalli 'under the granary' (where äita 'granary', alli 'under'), põ̃randalli 'underground' (where põ̃rand 'ground', alli 'under'), ōjtaggi 'place behind the stove' (where $\bar{q} j$ 'stove', taggi 'behind'). The Livonian-Estonian-Latvian dictionary contains a relatively wide range of these compounds: kirtaggi 'back of the head', küorataggi 'auricular', sälgataggi 'rear', katüksalli 'shed', käpalli 'under the wardrobe', lódanalli 'under the table', pänalli 'headrest', magalli 'underbelly' and others. In Latvian such compounds can also be found in toponyms: Muižapakša (a meadow in Dundaga parish), Mežapakš, Dārzapukš and others.

\section{Conclusion}

Until now, research regarding Livonian and Latvian language contacts has mostly focused on vocabulary and especially the influence of Livonian on Latvian onomastics; however, the mutual ties between the two languages are much deeper and broader, from common semantics up to reciprocal grammatical structural changes, research into which is important for full understanding of both languages and their development.

Language changes caused by language contacts occur only in close connection with the causes of each language's internal development (Nītiņa 1972: 18). Livonian grammatical changes caused by Latvian (and vice versa) indicate close contacts between the linguistic communities and common material, as well as spiritual and cultural space.

As observed in the article, Latvian has deeply and broadly influenced many different aspects of Livonian. As previously stated, Livonian has similarly affected Latvian. Unfortunately, there aren't enough earlier materials in and about Livonian, nor have there been enough studies of the contacts between both languages to clearly observe the reciprocal influences of the two languages.

When making this insight into the issues of Livonian and Latvian language contacts, it can be concluded that multiple phenomena in 
Latvian and Livonian can be observed as parallels in neighbouring languages. To understand and evaluate the mutual influences between Livonian and Latvian, more contrasting studies are necessary, which would encompass the entire Baltic and Finnic communication range i.e., Estonian, Livonian, Latvian languages and their dialects, taking into account neighbouring Finnish and Lithuanian languages and not forgetting even broader contacts with Russian, German, Polish and Swedish languages. Only then would it be possible to gain a comprehensive view of the Livonian and Latvian, Baltic and Finnic language interactions.

\author{
Addresses \\ Valts Ernštreits \\ Institute of Estonian and General Linguistics \\ University of Tartu \\ Jakobi 2 \\ 51014 Tartu, Estonia \\ E-mail:valt@ut.ee \\ Gunta Kl̦ava \\ Latvian Language Agency \\ Lāčplēša 35-5, \\ LV-1011 Riga, Latvia \\ E-mail: gunta.klava@valoda.lv
}

\begin{abstract}
Abbrevations
ABL - ablative, ACC - accusative, ADE - adessive, ALL - allative, AUX - auxiliary, COM - comitative, DAT - dative, Est. - Estonian, Fin. - Finnish GEN - genitive, ILL - illative, IND - indicative, INE inessive, INS - instrumental, Liv. - Livonian, LOC - locative, Lith. Lithuanian, Latv. - Latvian, PART - partitive, PL - plural, PRS present, PST - past, Rus. - Russian, SG - singular, SUP - supine, TRA - translative
\end{abstract}

\title{
Sources
}

JS 2011 = Kōrli Stalte (2011) Jelzi sõnā. Ābēd ja irrgandõks lugdõbrōntõz. Tartu: Jemākīel seḷtš; Līvõ Kultūr Sidām. 
LEL = Tiit-Rein Viitso, Valts Ernštreits (2012) Līvõkīel-ēstikiel-lețkiel sõnārōntõz. Liivi-eesti-läti sõnaraamat. Lībiešu-igauņu-latviešu vārdnīca. Tartu, Rīga: Tartu Ülikool, Latviešu valodas aǵentūra.

Mt 1863 = Das Evangelium Matthäi in den östlichen Dialect des Livischen zum ersten Male übersetzt von dem Liven N. Pollmann, durchgesehen von F. J. Wiedemann. London, 1863.

Statūti 1923 = Lìvõd İt alizkēra. Tartu, 1923.

\section{References}

Alexandra Y. Aikhenvald and R. M. W. Dixon (2007) Grammars in contact. a crosslinguistic typology. Oxford: Oxford University Press.

Bušs, Ojārs (2008) No germānismiem lìdz superlatīvam. Rīga: LU Latviešu valodas institūts.

Endzelīns, Jānis (1951) Latviešu valodas gramatika. Rīga.

Ernštreits, Valts (2011) Lībiešu rakstu valoda. Rīga: Latviešu valodas aǵentūra.

Grünthal, Riho (2003) Finnic adpositions and cases in change. Helsinki.

Heine, Berndt and Tanie Kuteva (2006) The changing languages of Europe. Oxford: Oxford University Press.

Laakso, Johanna (2010) "Contact and the Finno-Ugric languages". In R. Hickey, ed. The handbook of language contact, 598-618. Malden, MA: Wiley-Blackwell.

LVG 2013 = Latviešu valodas gramatika (2013) Rīga: LU Latviešu valodas institūts.

Nīinina, Daina (1972) "Vispārīgās valodniecības jautājumi akad. J. Endzelīna darbos". Veltījums akadēmiķim Jānim Endzelīnam, 11-23. Rīga: Izdevniecība Zinātne.

Rudzīte, Marta (1996) "Latviešu un lībiešu valodas kontaktu atspulgi”. In P. Vanags, atb. red. Baltu filologija VI: Rakstu krājums, 6. laidiens, 3-7. Rīga: Latvijas Universitāte.

Rudzīte, Marta (1994) "Latviešu un lībiešu valodas savstarpējā ietekme”. Lībieši Rakstu krājums, 288-319. Rīga : Zinātne.

Sankoff, Gillian (2001) "Linguistic Outcomes of Language Contact". Peter Trudgill, J. Chambers and N. Schilling-Estes, eds. Handbook of Sociolinguistics, 638-668. Oxford: Basil Blackwell.

Seržants, Iljja (2012) "Vēsturiskā valodniecība un latviešu valodas". Valodas prakse: vêrojumi un ieteikumi 7, 58-73. Rīga: Latviešu valodas aǵentūra.

van Goethem, Kristel (2008) From adjective to prefix: lexicalization and grammaticalization of French ancien/ nouveau $+N$. University of Leuven. Available online at <http://www.ling.arts.kuleuven.be/nrg4/_pdf/vangoethem.pdf $>$. Accessed on 20.03.2012.

Vääri 1994 = Vēri, Eduards (1994) "Īss lībiešu valodas apraksts”. Lībieši. Rakstu krājums, 267-288. Rīga: Zinātne.

Zinkevičius, Zigmas (1984) Lietuviu kalbos istorija 1: Lietuviu kalbos kilmé. Vilnius: Mokslas. 
Kokkuvõte. Valts Ernštreits ja Gunta Kḷava: Liivi ja läti keele kontaktide poolt põhjustatud grammatilised muutused. Artikkel annab ülevaate mitmesugustest grammatilistest muutustest, mis on toimunud liivi ja läti keeles pikaajaliste kontaktide tulemusel. Läti keel on tugevalt mõjutanud liivi keelt erinevatel keeletasanditel, kuna liivlased on olnud läti-liivi kakskeelsed juba pikka aega. Samuti on liivi keel mõjutanud läti keelt. Vastastikust laenamist on kõige selgemalt näha sõnavaras, eriti murretes. Siiski ka häälikusüsteemis ja grammatikas on kontaktide mõjul leidnud aset muutusi. Artiklis esitatakse uurimistulemusi konkreetsete käändesüsteemi muutuste kohta liivi keeles, nagu seda on väliskohakäänete kadu ja daativi moodustumine, translatiivi ja komitatiivi kokkusulamine ja selle tulemusel instrumentaali teke. Vaadeldakse ka prefiksite kujunemist, eitusstruktuure, läti keele lokatiivi tähenduslikku muutumist ja läti liitsõnade moodustamist liivi malli järgi ning perfektiivseid verbikonstruktsioone. Ehkki keele grammatilist struktuuri peetakse suhteliselt püsivaks kontaktsituatsiooniski, võivad muutused ilmneda ka mittesugulaskeeltes, kui neid on pikka aega räägitud ühes keeleareaalis. Liivi ja läti keele kontaktide tulemused näitavad seda selgelt.

Märksõnad: liivi keel, läti keel, keelekontaktid, grammatilised muutused

\footnotetext{
Kubbõvõttõks. Valt Ernštreit, Gunta Kḷava: Līvõ ja leț kīel kontaktiš suggõnd gramatīk mõitõkst. Kēra nīžõb iḷ setmiņsuglizt mõitõkst līvõ ja leț kīel gramatīks, mis alīzõks āt pitkāāigalizt kontaktõd līvõ ja leț kīel vaisõ. Leț kīelõn um vỏnd sūr mỏj līvõ kīelõn setmin kīelarāl, sīestõ līvlizt jõvā pitkõ aigõ ātõ vỏnnõd kōdkēlizt ja kỗlbatõnd nei līvõ, ku ka leț kīeldõ. Selli īž um ka līvõ kīel mỏj lețkīels. Amā jemīṇ um täpīṇtõd sõnāvīḷa, īžkist kīelmūrdiš, bet kontaktõd āt jettõn eņtš tīedõzt ka īeld sistēms ja gramatîks. Kēras um vaņtõltõd nõtkõmd sistēm mõitimi līvõ kīels, nägțõbõks ulzizt kūožnõtkõmd kaddimi ja datīv suggimi, translatīv ja komitatīv kubbõ sullimi ja obbimi instrumentāl suggimi. Um vaņtõltõd ka prefiksõd suggimi, negātsij struktūrd, leț kīel lokatīv täntõkst mõitimi, leț îtsõnād lūomi līvõ sistēm pierrõ, ja perfektīvizt tīemizsõnād konstruktsijd. Laz kil mõtlõbõd, ku gramatīk struktūr um dižānist pīldzi ka kīelkontaktiš, mõitõkst võibõd sugggõ ka nēši kēlsši, mis äb ūotõ sugūd, až ne ātõ pitkõ aigā kồlbatõd sīes īž kīel areāls. Livõ ja leț kīel kontaktõd nägțõbõd sīe sieldistiz.
} 